\section{DEVELOPMENTS IN ADULT EDUCATION}

Trends in English Adult Education

Edited by Prof. S. G. Raybould. Pp. xiii +258 . (London : William Heinemann, Ltd., 1959.) $21 s$. net.

THE most remarkable feature of this book is that it should have been written at all. During the great debate of less than ten years ago some of the contributors to the book vociferously championed the pure white flag of liberal adult education and completely rejected all the mixtures which went under the false colours of extension classes, local education authority activities, informal pursuits, broadeasting and the like. Yet here is a book, more than half of which is concerned with trends quite unrelated to the traditional conception of adult education in Great Britain. It is a fine tribute both to the vigour of adult education itself and to the flexibility and resource of those who promote it.

With two exceptions, the contributors are all drawn from the department of adult education at the University of Leeds. They, and particularly the editor, deserve warm praise for setting down their recent experiences in such forthright, objective and yet provocative fashion; this applies no less to the two distinguished contributors from outside the University walls.

The great debate about the purpose and content of adult education was sparked off by Prof. S. G. Raybould himself in 1949. The issue, quite simply, was whether or not the time-hallowed name of adult education could be given to any activities unconnected with the tutorial classes which had been jointly developed by the Workers' Educational Association and university extra-mural departments. How the debate proceeded-and how other adult education activities developed apparently with the connivance of those who opposed them-is carefully set out in a well-written chapter by Roy Shaw. This, surely, should have been the starting point of the book.

The controversial place of the Workers' Educational Association in the adult education movement of to-day is carefully analysed by a great friend of the movement, J. F. C. Harrison. Regretfully he arrives at the only possible conclusion that the Association is but a shadow of its former self, has failed to adjust its aims and organization to the needs of 1959 , and with bewilderment and frustration arising from lack of national leadership, stands in marked contrast to the buoyancy and optimism which marks the university adult education movement of to-day.

The latter is described by J.W. Saunders. Since 1945 the virtual monopoly of university services by the Workers' Educational Association has been challenged by education directly provided by the extra-mural departments of the universities, now recognized as 'responsible bodies' by the Ministry of Education. Besides traditional classes for the 'workers', extra-mural departments are providing an ever-increasing number of specially designed courses to appeal to specialized professional people and to students who have had the privilege of a secondary and even a university education; "new social pur. poses, new social fulfilments are being met". If, as Sir Charles Morris writes in the foreword to this book, "at all stages a great part of education must always be self-education", the university extension movement is surely right to give urgent attention to the quality and standard of people who emerge from schools and universities into a world of specialists.

Other chapters describe the increasing attention paid to adult education by local authorities; the direct contribution of broadcasting and, incidentally, the value of market research in giving the customer what he requires; the immeasurable value of residential adult education colleges by their most worthy exponent, Guy Hunter; the educational influences of organizations such as Women's Institutes, Townswomen's Guilds and various local societies; some experimental work in trade union education which needs to be followed up with much greater enthusiasm than appears to be the case ; and finally, a review by Prof. Raybould of developments since the Ashby Report was published in 1954. Most of the recommendations set out in that Report have been implemented ; their influence on adult education trends have been considerable. One recommendation made by the committee was that sooner or later adult education must fight for a due share of the finances of universities, instead of continuing to be a branch of university activity protected by ear-marked grants from the Ministry of Education. Prof. Raybould believes that the time to adopt this recommendation has arrivod. His views are earnest and compelling and could well initiate another great debate.

T. H. Hawkins

\section{THE PSYCHOPATHOLOGY OF SCIENCE}

\section{The Sleepwalkers}

A History of Man's Changing Vision of the Universe. By Arthur Koestler. Pp. 624. (London: Hutchinson and Co. (Publishers), Ltd., 1959.) 25s. net.

THE story of the substitution for the tight, cosy,

Earth-centred world of Aristotle of the infinite, centreless, mechanistic universe of Newton is a drama which the dullest of historians could not conceal; it is told again by Mr. Koestler with all the stylistic verve of an experienced novelist and with adroit use of the materials and ideas pieced together by historians of science during the past two generations. Through detailed studies of Copernicus, Kepler and Galileo as examples of the medieval, the transitional and the 'terrifyingly modern' scientific mentality the author has succeeded brilliantly in giving the general reader a vivid account of what the change from medieval to modern cosmology involved. For this is the core of the book; nothing between Aristarchos and Copernicus holds much interest for Mr. Koestler, and his account of cosmology after Galileo is equally brief. Newton's austere mind commands his admiration, but not his imaginative sympathy.

Although he makes effective-not invariably quite accurate- use of recent work in the history of science, Mr. Koestler's opinions will not always commend themselves either to scholars or to scientists. $\mathrm{He}$ constantly under-rates Ptolemy's great achievement because he finds the theory of epicycles ridiculous, while recognizing that the epicycles were tools of mathematical analysis and not regarded as physical realities. Conversely, he argues that Galileo should have been satisfied with the status of the Copernican system as a "working hypothesis", since he could not prove its de facto truth. Yet the Church was only 